\title{
Knowledge Management Functions Applied in Jordanian Industrial Companies: Study the Impact of Regulatory Overload
}

\author{
Muzhir Shaban Al-Ani', Shawqi N. Jawad², Suha Abdelal'² \\ ${ }^{1}$ Department of Information Technology, University of Human Development, College of Science and Technology, \\ Sulaymaniyah, KRG, Iraq, ${ }^{2}$ Department of Management, Amman Arab University, College of Business, Amman, Jordan
}

\section{A B S T R A C T}

This research aims to study the impact of electronic information overload on knowledge management functions in Jordanian industrial companies. The research population included all Jordanian industrial companies listed on the Amman Stock Exchange. A simple random sample of $30 \%$ of the research population of 1242 seniors and middle managers in the research population was done to 373 individuals. 206 questionnaires are successfully retrieved to be analyzed. Descriptive and heuristic statistical methods such as simple and multiple regression analysis were applied using SPSS.16 program. The obtained result indicated that there is a statistically significant impact of the electronic information overload (organizational overload) on the knowledge management functions (acquisition, generation, transmission, sharing, and application of knowledge) in Jordanian industrial companies. In the scope of the results, this work made a number of recommendations, including: Adopting an organizational aspect that suits the nature of the tasks that the industrial companies operate in Jordan, in addition to providing technical capabilities to reduce the electronic information overload faced by the industrial companies in Jordan while practicing their tasks.

Index Terms: Knowledge Management, Organizational Overload, Statistical Analysis, Jordanian Industrial Companies

\section{INTRODUCTION}

The last decades and the present century have witnessed an acceleration in the pace of change toward the knowledge economy, as the production and organization of knowledge have become a top priority for business organizations [1]. Knowledge is an essential ingredient for driving economic growth in countries [1]. Knowledge has already become an intangible asset of the organization, prompting organizations to rearrange their priorities (National Information Technology

\begin{tabular}{|l|l|}
\hline \multicolumn{2}{|c|}{ Access this article online } \\
\begin{tabular}{l|l|} 
DOI: 10.21928/uhdjst.v5n2y2021.pp47-56 & E-ISSN: 2521-4217 \\
P-ISSN: 2521-4209
\end{tabular} \\
\hline
\end{tabular}

Copyright (c) $2021 \mathrm{Al}-\mathrm{Janabi}$, et al. This is an open access article distributed under the Creative Commons Attribution Non-Commercial No Derivatives License 4.0 (CC BY-NC-ND 4.0)
Council, 2004) [2]. Many technological applications have been developed that have enhanced organizational capabilities and have created a huge influence of information and their use in organizations [3].

Business organizations now face a clear challenge as a result of the knowledge and technical revolution in all areas of knowledge [4]. Effective decision for enabling senior management to enhance its role in investing in technical and knowledge developments is very important to face the turbulent environment and its requirements [5]. It is necessary to identify theoretical foundations and theoretical structures that are capable of achieving the goals of the organization [6]. Business organizations in general and industrial companies in particular are affected by the dramatic change in the business environment and its drive toward the use of information technology in which information has become a key resource

Corresponding author's e-mail: Muzhir Shaban Al-Ani, Department of Information Technology, University of Human Development, College of Science and Technology, Sulaymaniyah, KRG, Iraq. muzhir.al-ani@uhd.edu.iq

Received: 14-09-2021

Accepted: 28-10-2021

Published: 04-11-2021 
for the growth and progress of these organizations [7]. The information becomes the most important in terms of its accessibility and storage in electronic databases and then reemployment in which generated the overload of electronic information [8].

Knowledge management is one of the most recent topics in the world of management and it is of great interest to stakeholders in business organizations Sekaran, [9]. In addition, this increased of interest in the rush of organizations of various types toward the possibility of applying knowledge [10]. Knowledge management is gateway to the development of contemporary organizations to enable them to meet future challenges [10]. The significance of knowledge management in business organizations is not in the knowledge itself, but in the value added to these organizations, in addition to the role it plays in transferring organizations to the knowledge economy that emphasizes investment in knowledge capital [11].

The business environment of organizations is characterized by rapid change, dominated by the information and communication revolution [12]. Knowledge is the weapon adopted by organizations to ensure their growth and sustainability [13]. Participatory knowledge is widespread and increased by practice and use. Knowledge is an important resource that contributes to the success of various organizations [14].

Modern business organizations constantly strive to adapt in every stage of development in the knowledge economy and keep pace with the requirements of the era [12]. Electronic information systems have become the basis for management and productivity processes in business organizations of all kinds (Bawden and Robinson, 2008) [13]. These systems are playing a clear role in the processes related to the objectives, business, marketing, and productivity of the organizations [14].

This study is characterized by the fact that it verified the regulatory overload in electronic information within the Jordanian industrial companies. This was done through a survey questionnaire to study the reality of these companies within this new environment. This study is the first of its kind in this field and within the Jordanian industrial sector.

\section{STATEMENT OF THE PROBLEM}

The organization and its staff face with the phenomenon of information overload that requires attention, study, and treatment. Since the companies in general and the Jordanian industrial companies in particular deal with the large amount of information that is available as electronic data. This weakens their position in making various decisions and makes mistakes due to the excessive overload in the aspects of knowledge information. This requires companies to find a new mechanism to enable them to meet these overloads with the importance of finding a form of control over the application of this mechanism to determine the prospects for dealing with their data.

Therefore, the research seeks to measure the "Knowledge Management Functions Applied in Jordanian Industrial Companies: Study the Impact of Organizational Overload."

\section{RESEARCH QUESTIONS}

The following questions are achieved to perform the research:

- What is the level of managers' perceptions of the regulatory overload in two dimensions (channels of communication and regulatory environment) in Jordanian industrial companies?

- What is the level of managers' perceptions of the regulatory overload in two dimensions (communication channels and regulatory environment) in the Jordanian industrial companies?

- What is the level of perceptions of managers in the impact of the regulatory overload on the functions of knowledge management dimensions (acquisition, generation, transport, sharing, and application of knowledge) in the Jordanian industrial companies?

\section{RESEARCH OBJECTIVES}

The research hopes to achieve the following objectives:

- Measuring the impact of variables related to the electronic information (regulatory overload) on knowledge management functions in the researched companies

- Identify the positive aspects that help to improve knowledge management functions and the negative aspects that limit the effectiveness of these functions

- Measuring the level of application of knowledge management functions by industrial companies in Jordan; to reach appropriate recommendations that can be made to deal with electronic information (regulatory overload). 


\section{RESEARCH HYPOTHESIS}

There is no statistically significant effect at the level $(\alpha \leq 0.05)$ of the regulatory overload (channels of communication and regulatory environment) in the knowledge management functions (acquisition, generation, transmission, sharing, and application of knowledge) in Jordanian industrial companies.

\section{RESEARCH MODEL}

The study model is designed with its variables regarding to the problem of the study and its hypothesis and to achieve its purpose and reach its specific objective (Fig. 1).

\section{ELECTRONIC INFORMATION OVERLOAD}

The overload of electronic information in businesses companies is very important and requires a series of creative measures to be achieved.

The use of electronic data warehouse and the application of electronic knowledge in the organization are constantly re-using knowledge within the organization [16]. Noted that technology caused the explosion of information due to the lower costs of multimedia technology, which simplified access to information and helped in their publication. As Whelan and Teigland, 2010, [16] explained, the information overload is a problem facing contemporary organizations.

According to Himma, 2007, [17], there is a difference in meaning between these two terms, contrary to what some think that the overload means an increase. This was made clear when the excess quantity was seen as a precautionary

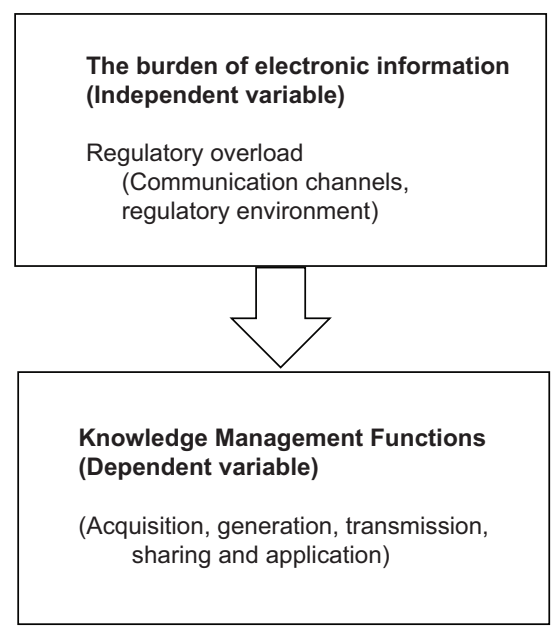

Fig. 1. Research model. measure. Therefore, this quantity had no negative effect and could be dealt without incurring high costs. If this increase becomes negative for individuals and becomes problematic, in which there is an overload.

Eppler and Mengis, 2003, [15] indicated that the overload of information appears on the receipt of a large amount of information beyond the capacity of individuals to deal with a process, which reflects negatively on the quality of the decision. Grise and Gallupe [18] defined the overload of information as having a lot of information with the inability of the individuals concerned with that vast amount of information. Mulder et al., 2006, [19] added that the information overload increases the sense of tension when the volume of information exceeds the capacity to be processed. Kim et al., 2007, [20] considered that the information overload meant confusion in the information received that impeded learning and impaired individuals' decision-making capacity.

Farhoomand and Drury, 2002, [21] have warned that the information overload may be created by situations such as the Web and the Internet, which are the main reasons for the overloads because of the abundant information you provide from external resources. The complexity of organizational tasks and the lack of sufficient number of people to complete the tasks, which all lead to an information burden, as well as the huge amount of information coming to the offices of managers daily. Not to mention the availability of a lot of information that is not understood by individuals or not knowing whether this information serves their orientation or not (Dubosson and Fragniere, 2009) [22].

Lesa, 2009, [23] reported that the regulatory overload is endemic in today's fast-track environment. Inadequate regulatory environment for organizational learning impedes the flow of information, ideas, and knowledge into the organization, resulting in an information overload. Lesa, 2009, [23] mentioned that there are a number of strategies for dealing with the information overload at the organizational level, including: Establishing task-specific task forces, building informal relationships across the organizational structure and applying modern information management systems. The organizational overload (Wilson, 2001) [24] is also a situation in which the information overload flowing widely from individuals across the organizational structure is reflected in a reduction in the overall effectiveness of the organization's operations management. Filippov and Iastrebova, 2010, [25] explained that the regulatory overload implies an imbalance between the requirements for processing organizational information and the ability to process that information 
within the organization. The organizational structure helps facilitate the collection, processing, and dissemination of information and the protection of individuals from the burden of information.

Below some concepts that clarify knowledge will be addressed:

\subsection{Knowledge}

Information combined with experience and intuition (Yan, 2009) [26]. That is, knowledge is information that has been processed, organized, and structured to be applicable (Hester, 2009) [27]. Knowledge consists of a combination of values, contextual information, and expertise, as well as new information and expertise that exists in knowledgeable minds, organizational routines, documents, rules, processes, and practices in organizations (Haytham, 2005) [28]. Knowledge is also seen as an intellectual capital and a critical component of today's organizations and is growing with increasing practice and learning (Najm, 2005) [29]. As knowledge is a combination of experience, practice, judgments, and values of both the individual and the organization that are reflected in the work of employing knowledge for the desired goals (Salwa, 2008) [30].

There are two types of knowledge: Tacit knowledge and explicit knowledge. Tacit knowledge is the knowledge stored in human minds and behavior, and what is generated by learning from past experiences that are difficult to document and transfer to others. Explicit knowledge is knowledge that can be shared among individuals, groups, and organizations and can be documented, stored electronically, transmitted and used through various means (Jazar and Talaat, 2005) [31].

\subsection{Knowledge Management}

Fernandez et al., 2004, [32] defined knowledge management as doing what is needed to maximize the benefit of knowledge resources. Since knowledge management is the gateway to adding and generating value by mixing knowledge elements to create better knowledge combinations, this will change the role of data, information and knowledge to flow individually (Najm, 2005) [29]. Mohammed and Ziad, 2010, [33] described knowledge management as the organization's knowledge resources and assets, adaptability and learning, increasing the creative process, sharing and optimal use of these assets. Ashoc, 2004, [34] also noted that knowledge management is effective learning processes associated with the exploration, exploitation, and sharing of human knowledge (explicit and Tacit), which applies appropriate civilization, technology, and culture to extract performance and intellectual capital.
Regarding to the organizational implications of knowledge management, it was pointed out that knowledge management contributes to the generation of knowledge that seeks to improve the performance of organizations through four dimensions (Fernandez et al., 2004) [32]. These dimensions are influencing individuals, influencing processes, influencing product, and influencing organizational performance.

There are five knowledge management functions as follows:

- Knowledge acquisition: Knowledge acquisition is a function that seeks to gain knowledge and obtain it from a variety of documented sources, as well as the acquisition of undocumented sources that stored in the minds of individuals and issued through their behavior. Knowledge can be gained from experts and stakeholders and information technology plays an important role in supporting knowledge acquisition through its role in data capture, classification, processing, and harnessing to build the competitive advantage of an organization (Kamel, 1999) [35]. The function of knowledge acquisition goes through four stages (Kamel, 1999) [35]: Collection, interpretation, analysis, and design

- Knowledge generation: Knowledge generation comes from a variety of sources and channels to expand the repositories of organizational memory and enable the organization to creatively solve solutions to its problems leading to innovation. It is individuals who generate knowledge within the organization. This will be done through four processes of knowledge transfer: Social participation, embodied external knowledge, integrated internal knowledge, and synthetic knowledge

- Knowledge transfer: Knowledge transfer depends on several factors that need to be considered: leadership, support for organizational structures, absorptive capacity, degree of privacy, degree of complexity, and dependability of knowledge vocabulary. Knowledge is transferred through the use of management information systems, training and e-learning systems using the internet (Ashoc, 2004; Alavi and Leidner, 2001) [10], [34]

- Knowledge sharing: Knowledge sharing is an important element in production, responding to environmental changes, promoting opportunities, outperforming competitors, and maintaining the effectiveness of modern organizations. The knowledge base of the organization is increasingly shared by individuals with their knowledge and experience formally through regular formal meetings. The sharing of knowledge with individuals prevents the loss, fading and erosion of that knowledge over time. In addition, sharing knowledge between organization and other organizations 
enhances the knowledge storage that will be available in organization repositories from those of other organizations [36]

- Knowledge application: It is a knowledge management purpose where modern organizations apply knowledge using web-based technology systems and knowledge retrieval techniques. Furthermore, these systems provide the ability to access, transfer and use information in a timely and appropriate manner and to communicate with the right person [36].

Zainab, 2009, [37] presented a case study of King Abdul Aziz University, which measured the readiness of organizations to apply knowledge management through the four dimensions of knowledge management (human dimension, technological dimension, strategic dimension, and operations dimension). He concluded that KAU has a readiness to manage knowledge with a medium degree. Carlevale, 2010, [38] concluded that technology causing the information overload caused by the huge amount of e-mail that managers are exposed to every day in which generating more pressure. That e-mail is the biggest cause of the burden of information on these managers on a daily basis, hinders the decision-making process and that incoming emails need to be filtered and managed.

Hodge, 2010, [39] noted that there is a positive correlation between knowledge management processes (capturing, storing, classifying, and applying) and knowledge management capabilities (lessons learned, experiences, and knowledge documents). Salwa, 2008, [30] emphasized the role of knowledge management and information technology in achieving competitive advantages that concluded the banks in question apply the knowledge management technology system in all units and departments within banks, although there is no organizational unit or special department for knowledge management and information technology. Inside any bank (Ismail and Yusof, 2010) [40] showed that there is a positive relationship between individual factors (awareness, confidence, and personality), and the quality of knowledge sharing. Personal style (extrovert and introvert) is the most important for the quality of knowledge sharing followed by trust and awareness.

\section{METHODOLOGY}

\subsection{Research: Questionnaire Design}

The overload of electronic information in businesses companies and the relevant factors and tasks that have been explained in the previous sections. This section explains how the questionnaire is designed and what are their paragraphs. The questionnaire is designed based on the Likert scale of five fields: Strongly agree, agree, neutral, disagree, and strongly disagree. Regarding to the research model the designed questionnaire is divided into: Independent variable (regulatory overload) and dependent variable (knowledge management functions).

- Independent variable (Regulatory Overload) (Fig. 2): This field is divided into two parts: Communication channels and regulatory environment. Communication channels related to loss of boundaries between roles, tasks and work duties, which affects the movement and exchange of information within the departments of a single organization due to the inadequacy or lack of clarity of the organizational structure. Regulatory environment related to the availability of work requirements in the work environment through which the organization can control the variables of its environment of humans, devices and the administrative decisions

- Dependent variable (knowledge management functions) (Fig. 3): This field is divided into five parts: knowledge acquisition, knowledge generation, knowledge transfer, knowledge sharing, and knowledge application. Knowledge acquisition according to obtain knowledge from various internal sources (such as collaboration, learning, feedback from staff, workshops, training programs, and databases within which knowledge is stored) and external (such as competitors, customers, consultants, attract experienced and competent personnel, and establish relationships with partners and allies). Knowledge generation regarding to derive and create new creative knowledge from existing knowledge within the organization to secure various types of knowledge for the benefit of future decisions which are concerned with equipping workers in the knowledge field with graphics and analysis, and this is done through teaching, learning, research, and development. Knowledge transfer related to communicate the right knowledge to the right person in the appropriate manner (communications, bulletins, reports, staff movements, and use of technological means to facilitate knowledge transfer), and unintentional (informal meetings of individuals) at the right cost and at the right time. Knowledge sharing regarding to circulate and exchange of various types of knowledge among individuals. Interacting with others' dialogues inside and outside the organization, securing collective cooperation among them, reaching out and working simultaneously on the same document and from different locations to form new creative mental ideas. Knowledge application 
Al-Ani, et al.: The Impact of Regulatory Overload in Jordanian Companies

\begin{tabular}{|c|c|c|c|c|c|c|c|c|c|c|c|c|c|}
\hline$\#$ & Description & $\begin{array}{l}\text { Strongly } \\
\text { agree }\end{array}$ & Agree & Neutral & Disagree & $\begin{array}{l}\text { Strongly } \\
\text { disagree }\end{array}$ & \# & Description & $\begin{array}{l}\text { Strongly } \\
\text { agree }\end{array}$ & Agree & Neutral & Disagree & $\begin{array}{l}\begin{array}{l}\text { Strongly } \\
\text { disagree }\end{array} \\
\end{array}$ \\
\hline \multirow[t]{2}{*}{1} & \multirow{2}{*}{$\begin{array}{l}\text { The technological burden affects the } \\
\text { company's departments and internal } \\
\text { departments' interaction with the } \\
\text { communication network for information } \\
\text { exchange. }\end{array}$} & & & & & & 7 & $\begin{array}{l}\text { The company is slow to provide business } \\
\text { requirements in the electronic environment } \\
\text { when the technological burden increases. }\end{array}$ & & & & & \\
\hline & & & & & & & 8 & $\begin{array}{l}\text { The working environment gets worse as the } \\
\text { technological burden increases. }\end{array}$ & & & & & \\
\hline 2 & $\begin{array}{l}\text { The administrative organization of the } \\
\text { company is suitable for business flow. }\end{array}$ & & & & & & \multirow[t]{2}{*}{9} & \multirow{2}{*}{$\begin{array}{l}\text { The company's rush to have advanced } \\
\text { management technology systems, which makes } \\
\text { it unable to operate efficiently. }\end{array}$} & & & & & \\
\hline 3 & The key roles of working in the company, are & & & & & & & & & & & & \\
\hline \multirow[t]{2}{*}{4} & $\begin{array}{l}\text { clearly defined. } \\
\text { The exchange of information electronically } \\
\text { between company divisions is an additional }\end{array}$ & & & & & & 10 & $\begin{array}{l}\text { The technological burden is reflected in the } \\
\text { company's ability to control business variables } \\
\text { in the electronic environment. }\end{array}$ & & & & & \\
\hline & burden for employees. & & & & & & \multirow[t]{2}{*}{11} & \multirow{2}{*}{$\begin{array}{l}\text { The worsening of the technological burden } \\
\text { shows the problems of providing adequate } \\
\text { personnel. }\end{array}$} & & & & & \\
\hline 5 & $\begin{array}{l}\text { The technological burden complicates the } \\
\text { processing of data. }\end{array}$ & & & & & & & & & & & & \\
\hline 6 & $\begin{array}{l}\text { Administrative organization helps in achieving } \\
\text { efficient and effective business performance in } \\
\text { the company. }\end{array}$ & & & & & & 12 & $\begin{array}{l}\text { The large amount of information received, } \\
\text { reduces the effectiveness of the company's } \\
\text { operations. }\end{array}$ & & & & & \\
\hline
\end{tabular}

Fig. 2. Regulatory overload questioner.

\begin{tabular}{|c|c|c|c|c|c|c|c|c|c|c|c|c|c|}
\hline$\overline{\#}$ & Description & $\begin{array}{l}\text { Strongly } \\
\text { agree }\end{array}$ & Agree & \begin{tabular}{|l|l} 
Neutral \\
\end{tabular} & Disagree & \begin{tabular}{|l|l|}
$\begin{array}{l}\text { Strongly } \\
\text { disagree }\end{array}$ \\
\end{tabular} & $\#$ & Description & $\begin{array}{l}\text { Strongly } \\
\text { agree }\end{array}$ & Agree & Neutral & Disagree & $\begin{array}{l}\text { Strongly } \\
\text { disagree }\end{array}$ \\
\hline 1 & $\begin{array}{l}\text { The company receives feedback from } \\
\text { employees on a permanent basis. }\end{array}$ & & & & & & \multirow[t]{2}{*}{6} & \multirow{2}{*}{$\begin{array}{l}\text { The company always synthesizes information } \\
\text { collected from multiple sources, in order to } \\
\text { generate new knowledge. }\end{array}$} & & & & & \\
\hline \multirow[t]{2}{*}{2} & \multirow{2}{*}{$\begin{array}{l}\text { The company uses training programs and } \\
\text { workshops as a way to equip employees with } \\
\text { the necessary knowledge. }\end{array}$} & & & & & & & & & & & & \\
\hline & & & & & & & \multirow[t]{2}{*}{7} & \multirow{2}{*}{$\begin{array}{l}\text { The company adopts advanced R\&D policies } \\
\text { to generate new knowledge. }\end{array}$} & & & & & \\
\hline \multirow[t]{2}{*}{3} & \multirow{2}{*}{$\begin{array}{l}\text { The company acquires knowledge from its } \\
\text { partners or allies by establishing relationships } \\
\text { with them. }\end{array}$} & & & & & & & & & & & & \\
\hline & & & & & & & 8 & $\begin{array}{l}\text { The company provides incentives for new } \\
\text { innovations and knowledge. }\end{array}$ & & & & & \\
\hline 4 & $\begin{array}{l}\text { The company is keen to provide employees } \\
\text { with information consistent with its products }\end{array}$ & & & & & & 9 & $\begin{array}{l}\text { The company encourages brainstorming } \\
\text { among employees to generate new ideas. }\end{array}$ & & & & & \\
\hline 5 & $\begin{array}{l}\text { The company recruits experienced and } \\
\text { competent staff to work for it to enhance its } \\
\text { knowledge. }\end{array}$ & & & & & & 10 & $\begin{array}{l}\text { The company seeks to meet its knowledge } \\
\text { needs by bridging the knowledge gap. }\end{array}$ & & & & & \\
\hline$\#$ & Description & $\begin{array}{l}\text { Strongly } \\
\text { agree }\end{array}$ & Agree & Neutral & Disagree & $\begin{array}{l}\text { Strongly } \\
\text { disagree }\end{array}$ & $\overline{\#}$ & Description & $\begin{array}{l}\text { Strongly } \\
\text { agree }\end{array}$ & Agree & Neutral & Disagree & $\begin{array}{l}\text { Strongly } \\
\text { disagree }\end{array}$ \\
\hline 11 & $\begin{array}{l}\text { Company information flows smoothly across } \\
\text { functional boundaries. }\end{array}$ & & & & & & \multirow[t]{2}{*}{16} & \multirow{2}{*}{$\begin{array}{l}\text { The company employs informal meetings and } \\
\text { dialogues for the purposes of expanding } \\
\text { sharing of knowledge. }\end{array}$} & & & & & \\
\hline \multirow[t]{2}{*}{12} & \multirow{2}{*}{$\begin{array}{l}\text { The company contributes in sending } \\
\text { scholarships for specializations in order to } \\
\text { transfer knowledge. }\end{array}$} & & & & & & & & & & & & \\
\hline & & & & & & & 17 & $\begin{array}{l}\text { The company has an atmosphere of mutual } \\
\text { cooperation to support knowledge sharing. }\end{array}$ & & & & & \\
\hline 13 & $\begin{array}{l}\text { IT helps bring people in need of knowledge } \\
\text { closer to those who have it. }\end{array}$ & & & & & & 18 & $\begin{array}{l}\text { The company fosters a culture of knowledge } \\
\text { sharing among employees. }\end{array}$ & & & & & \\
\hline 14 & $\begin{array}{l}\text { The company encourages dialogue between } \\
\text { employees to impart knowledge. }\end{array}$ & & & & & & \multirow[t]{2}{*}{19} & \multirow{2}{*}{$\begin{array}{l}\text { The company provides multiple channels for } \\
\text { knowledge sharing (Internet, Extranet and } \\
\text { Intranet). }\end{array}$} & & & & & \\
\hline \multirow[t]{2}{*}{15} & \multirow{2}{*}{$\begin{array}{l}\text { The company makes periodic transfers } \\
\text { between departments and departments as a } \\
\text { means of knowledge sharing. }\end{array}$} & & & & & & & & & & & & \\
\hline & & & & & & & 20 & $\begin{array}{l}\text { The company holds meetings to discuss its } \\
\text { annual reports to get feedback. }\end{array}$ & & & & & \\
\hline$\#$ & Description & $\begin{array}{l}\text { Strongly } \\
\text { agree }\end{array}$ & Agree & Neutral & Disagree & $\begin{array}{l}\text { Strongly } \\
\text { disagree }\end{array}$ & & & & & & & \\
\hline 21 & $\begin{array}{l}\text { The organization holds training courses on } \\
\text { how to use and apply the knowledge gained to } \\
\text { achieve specific objectives. }\end{array}$ & & & & & & & & & & & & \\
\hline 22 & $\begin{array}{l}\text { Directors recognize that the Organization has a } \\
\text { non-invested knowledge balance. }\end{array}$ & & & & & & & & & & & & \\
\hline 23 & $\begin{array}{l}\text { The company uses modern technologies to } \\
\text { apply knowledge and invest its returns. }\end{array}$ & & & & & & & & & & & & \\
\hline 24 & $\begin{array}{l}\text { The management of the company is keen to } \\
\text { use the new knowledge generated by the } \\
\text { company. }\end{array}$ & & & & & & & & & & & & \\
\hline 25 & $\begin{array}{l}\text { The company is keen to ensure that employees } \\
\text { are aware of the methods of applying the } \\
\text { acquired knowledge. }\end{array}$ & & & & & & & & & & & & \\
\hline
\end{tabular}

Fig. 3. Knowledge management functions questioner.

dealing with the utilizing of knowledge to support innovation, development of people and resource, business improvement, using specific technology systems and knowledge dissemination channels at all organizational levels.

\subsection{Research: Population and Sample}

The study population consisted of the industrial companies listed in the Amman Stock Exchange, and the Inspection and Analysis Unit included all directors working in the higher managements (general managers, their assistants, or their representatives), as well as managers working in the middle managements (managers of the main departments and heads of departments). A relatively random sample of (1242) members of the sampling and analysis unit, $(30 \%)$ was selected to become the sample (373). The number of questionnaires valid for statistical analysis (206) questionnaires $(55 \%)$ of the total questionnaires distributed. Regarding to data sources to achieve the objective of the study, secondary sources were adopted, which include those data and information published in various library sources for review of previous literatures. The primary sources of data were the questionnaire built for this purpose which was aimed at obtaining the raw data to complete the applied aspect of the study in terms of handling the study questions and testing the hypotheses. 


\section{RESULTS AND DISCUSSION}

Descriptive statistical analysis of study variables is applied on the obtained data. A low (less than 2.33), middle (2.33-3.66), and high (3.77 and above) was used to determine the relative importance of the respondents' perceptions of the study questions based on the Likert- 5 scale, and the arithmetic and standard deviations are shown in Fig. 4.

Question 1: What is the level of perceptions of managers working for the regulatory overload (channels of communication and regulatory environment) in Jordanian industrial companies?

The results of Fig. 1 show that the level of perceptions of the respondents regarding the regulatory overload was high and the researchers attribute the result to the fact that the administrative organization in the industrial companies serves the nature of the work adopted in the presence of electronic systems. Regarding the regulatory environment, the result indicates that there is an average level of influence of the

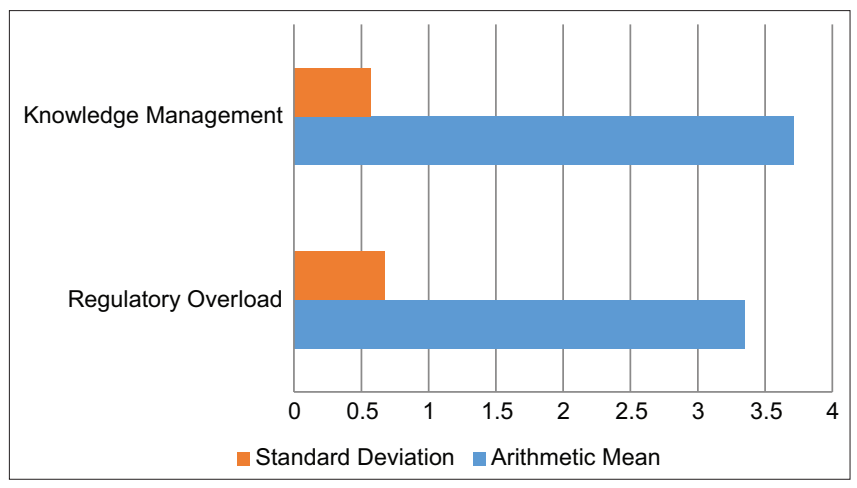

Fig. 4. Arithmetic mean and standard deviation (regulatory overload). regulatory environment as one dimension of the regulatory overload on knowledge management where the general arithmetic mean of the type of technology was (3.35) and the standard deviation (0.67).

Question 2: What is the level of perceptions of managers working for knowledge management functions (acquisition, generation, transmission, sharing, and application of knowledge) in Jordanian industrial companies?

The results of Fig. 1 indicate that the respondents' level of response was high where arithmetic mean is 3.71 and the standard deviation is 0.57 . The roles of the work they do and this knowledge are done in accordance with the surrounding environment, as they derive from the external environment that reflects the relations of companies with customers, as well as the relationships between companies at the level of industry.

Multiple regression and the accompanying tests are used to verify the validity of the hypotheses. In addition, F-test for the regression model significance, $t$-test for the significance of the effect, and the value of the coefficient of determination $\mathrm{R}^{2}$ are used to determine the interpreted percentage of independent variables in the dependent variable, depending on the statistical significance values extracted under the statistical software.

In this study, there is no statistically significant effect at $\alpha \leq 0.05$ level of the regulatory overload (communication channels and regulatory environment) in the knowledge management functions (acquisition, generation, transmission, sharing, and application of knowledge) in Jordanian industrial companies.

\section{TABLE 1: The impact of regulatory overload on knowledge management functions}

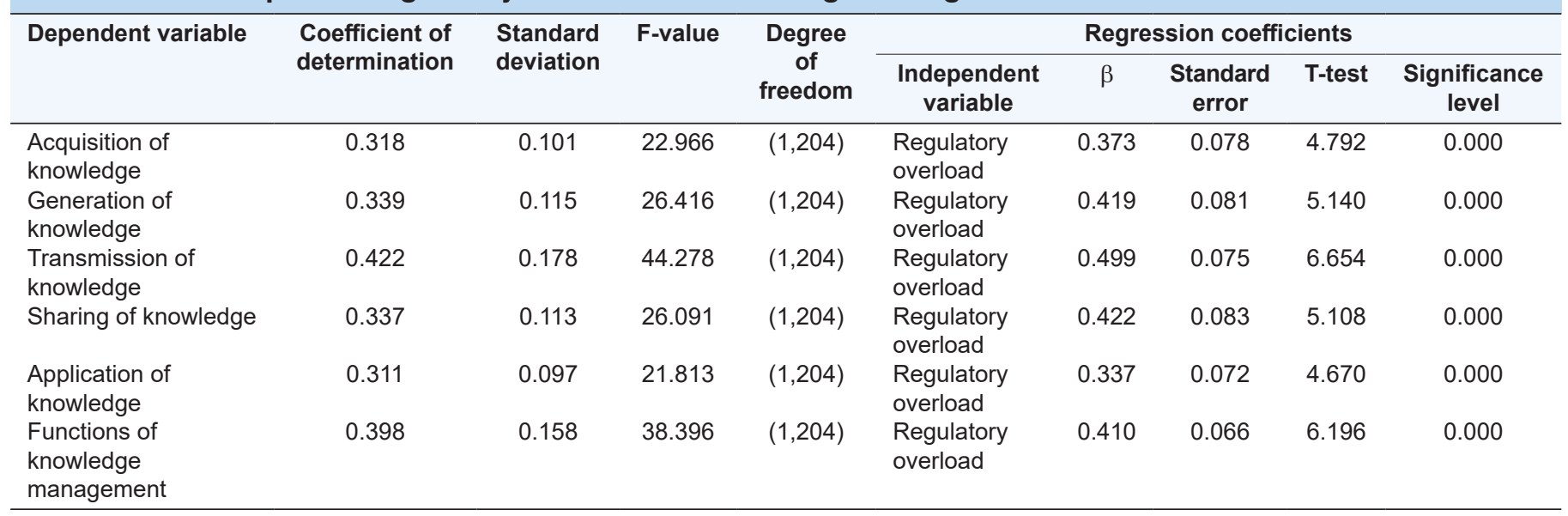


TABLE 2: Multiple regression analysis to test the effect of organizational burden dimensions on the dimensions of knowledge management functions



Table 1 shows that the simple regression model is applied to measure the impact of the organizational burden on the dimensions of knowledge management functions, in which have significant impact. This effect is significant based on the test value $(t=6.196)$ when compared with the value of the significance level $(\mathrm{sig}=0.000 \leq 0.05)$.

Table 2 indicates that multiple regression model to measure the effect of both dimensions (communication channels and organizational environment) in knowledge management functions is significant, where the value of $(\mathrm{F}=46.863)$ at the level of significance $($ sig $=0.000)$. Together, the two variables explain that $\mathrm{R} 2=31.6 \%$ of the differences in the values of knowledge management functions are reinforced by this result $(t=9.170)$.

\section{CONCLUSIONS}

Focusing of the previous discussions, the study reached a number of conclusions as below:

- The results of the study pointed to the relative importance of the regulatory overload in relation to the communication channels. This reflects that the roles of individuals are not clearly defined. The results of the study concur with (Lesa, 2009) [23] in the regulatory section, considering that regulatory factors are the primary cause of the information burden phenomenon according to (Lesa, 2009) [23]. The study also agreed with (Raoufi, 2003) [41] in terms of organizational factors, especially on the leadership side and their impact on the information overload created especially with those working in the field of knowledge

- The results in the level of importance of the regulatory overload in relation to the channels of communication in the Jordanian industrial companies coincided with the results of the analysis of the regulatory environment. (Manovas, 2004) [42], particularly in the field of knowledge transfer, learning culture, sharing, and incentive systems as elements of infrastructure in the regulatory environment

- The results of the study show that there is a high level of interest in knowledge generation due to the ability of managers to diversity knowledge sources and their focus on research and development and bridging knowledge gaps as a result of developments in the work environment and attention to the internal organizational dimension in the generation of knowledge through 
brainstorming processes. This result is consistent with the findings of the Zakia, 2009, [43] that studied on knowledge sources, acquisition and transmission. The results were also consistent with the Zainab, 2009, [37] which examined the dimensions and processes of knowledge management (acquisition, generation, transmission, distribution, and application) at King Abdulaziz University

- The results of the study demonstrated the impact of the regulatory overload (channels of communication and regulatory environment) on knowledge management functions (acquisition, generation, transmission, sharing, and application of knowledge) in Jordanian industrial companies from the point of view of managers working in Jordanian industrial companies. The results of the current study are consistent with the (Carlevale, 2010) [25] study, as reliance on communications technology creates a burden, especially e-mail, which creates a burden for managers and that e-mail needs to be filtered. This was also agreed with (Dubosson and Fragniere, 2009) [27] and (Lesa, 2009) [23].

\section{RECOMMENDATIONS}

Regarding to the results reached through the research, the researchers provide a number of recommendations to adopt them by the Jordanian industrial companies in the course of the research, so as to adapt them in reducing the burden of electronic information in term of regulatory overload and these recommendations as follows:

- Adopting the type of technology appropriate to the environment in which Jordanian industrial companies operate in such a way as to reduce the burden of information in term of regulatory overload that may be exposed in carrying out their decision-making tasks

- The Jordanian industrial companies should conduct a strategic analysis of the strengths and weaknesses that are reflected in the performance of the company's departments and departments and determine their impact on increasing or decreasing the regulatory overload in the departments

- Developing companies in their regulatory environment to achieve effective communication systems based on the concept of reducing the regulatory overload in an attempt to restructure their systems to achieve their effectiveness

- Companies continue to filter and exclude unnecessary information in a way that reduces the large amount of information that restricts the capabilities of the employees of the initiative and this does not negatively affect the capabilities of the public in providing initiatives in the field of electronic work, and not affected by the capabilities of employees in solving electronic problems.

\section{REFERENCES}

[1] S. N. Jawad, A. A. M. Shaban, H. H. Ali and I. Husen. "Small Business Management, a Technology Entrepreneurial Perspective". SAFA Publishing House, Amman, Jordan, 2010.

[2] National Information Technology Council (NITC). "Malaysia, (K-Economy-Introduction and Background)". 2004. Available from: http://www.nitc.org. [Last accessed on 2017 Dec 15].

[3] M. Song, H. Bij and M. Weggeman. "Factors for improving the level of knowledge generation in new product". $R \& D$ Management, vol. 36, no. 2, pp. 173-187, 2006. Available from: http://www.ssrn. com. [Last accessed on 2017 Dec 15].

[4] T. Asmahan and M. Ibrahim. "Requirements for Sharing Knowledge and Obstacles Facing its Application in Jordanian Telecommunication Companies, Presented to the Scientific Conference". Applied Science University, Amman, Jordan, 2007.

[5] A. A. M. Shaban and J. S. Naji. "Management Process and Information Technology". Al-Ethaa Publishing House, Amman, Jordan, 2008.

[6] A. A. M. Shaban and J. S. Naji. "Business Intelligence and Information Technology". Amman, Jordan, Safa Publishing House, 2012.

[7]. A. M. Sami. "Measuring the Impact of Organizational Culture Factors on the Implementation of Knowledge Management in the Jordan Telecom Group (Orange): Case Study, Unpublished Master Thesis, Graduate School of Administrative and Financial Studies". Amman, Jordan, Amman Arab University for Graduate Studies, 2008.

[8] N. Abboud. "Knowledge Management Concepts, Strategies and Operations". Dar Al Warraq, Amman, Jordan, 2005.

[9] U. Sekaran. "Research Methods for Business". $4^{\text {th }}$ ed. John Wiley \& Sons, Ltd., New York, United States, 2003.

[10] M. Alavi and D. Leidner. "Review: Knowledge management and knowledge management systems: Conceptual foundation and research issues". MIS Quarterly, vol. 25, no. 1, p. 107-136, 2001. Available from: http://www.ebsco.host.com. [Last accessed on 2017 Dec 15].

[11] Z. Mohammed. "Contemporary Trends in Knowledge Management". SAFAA Publishing and Distribution House, Amman, Jordan, 2008.

[12] M. Abbas. "Knowledge management and its effect on organizational innovation”. Journal of Arts Kufa, vol. 1, p. 257, 2008.

[13] D. Bawden and L. Robinson. "The dark side of information: Overload, anxiety, and other paradoxes and pathologies". Journal of Information Science, vol. 35, no. 2, pp. 180-191, 2008.

[14] L, Ruff. "Information Overload: Causes, Symptoms and Solution, Harvard Graduate School of Education's Learning Innovations Laboratory, (LILA)". 2002. Available from: http://www.lila. pz.harvard.edu/_upload/lib/infooverloadbrief.pdf. [Last accessed on 2017 Dec 20].

[15] M. Eppler and J. Mengis. "A Framework for Information Overload Research in Organizations: Insights from Organization Science, Accounting, Marketing, MIS, and Related Disciplines, ICA Working Paper". University of Lugano, Lugano, 2003. Available from: http:// www.bul.unisi.ch/cerca/bul/pubblicazioni/com/pdf/wpca0301.pdf. 
[Last accessed on 2018 Jan 10].

[16] E. Whelan and R. Teigland. "Managing Information Overload: Examining the Role of the Human Filter". 2010. Available from: http://www.ssrn.com. [Last accessed on 2018 Jan 10].

[17] K. E. Himma. "A preliminary step in understanding the nature of a harmful information-related condition: An analysis of the concept of information overload". Ethics and Information Technology, vol. 9, no. 4, pp. 259-272, 2007.

[18] M. L. Grise and B. Gallupe. "Information overload: Addressing the productivity paradox in face-to-face electronic meetings". Journal of Management Information Systems, vol. 16, no. 3, pp. 157-186, 2000.

[19] I. Mulder, H. de Poot, C. Verwij, R. Janssen and M. Bijlsma. "An information Overload Study: Using Design Methods for Understanding, Conference on Computer-Human Interaction: Design: Activities, Artefacts and Environments, Sydney, Australia". pp. 245-252, 2006.

[20] K. Kim, M. Lustria and D. Burke. "Predictors of Cancer Information Overload: Findings from a National Survey". 2007. Available from: http://www.informationr.net/ir/12-4/paper326.html\#mil56. [Last accessed on 2018 Jan 10].

[21] A. Farhoomand and D. Drury. "Managerial information overload". Communications of the ACM, vol. 45, no. 10, pp. 127-131, 2002.

[22] M. Dubosson and E. Fragniere. "The consequences of information overload in knowledge based service economies: An empirical research conducted in Geneva". Service Science, vol. 1, no. 1, pp. 56-62, 2009.

[23] B. Lesa. "The Impact of Organizational Information Overload on Leaders: Making Knowledge Work Productive in the 21 $1^{\text {st }}$ Century, Doctoral Dissertation". University of Idaho, United States, 2009.

[24] T.Wilson. "Informationoverload: Implicationsforhealthcareservices". Health Informatics Journal, vol. 7, no. 2, pp. 112- 117, 2001.

[25] S. Filippov and K. lastrebova. "Managing information overload: Organizational perspective". Journal on Innovation and Sustainability, vol. 1, no. 1, pp. 1-17, 2010. Available from: http:// www.revistas. pucsp.br/index.php/risus/article/view/4260. [Last accessed on 2018 Jan 10].

[26] X. Yan. "An Empirical Analysis of the Antecedents of Knowledge Management Strategies, Doctoral Dissertation". Nova Southeastern University, United States, 2009.

[27] A. Hester. "Analysis of Factors Influencing Adoption and Usage of Knowledge Management Systems and Investigation of Wiki Technology as an Innovative Alternative to Traditional Systems, Doctoral Dissertation". University of Colorado Denver, United States, 2009.

[28] H. Haytham. "Measuring the Impact of Knowledge Management Perception on Employment in Jordanian Organizations: A Comparative Analytical Study between the Public and Private Sectors towards Building a Model for Knowledge Management Employment, Unpublished Doctoral Thesis, Faculty of Administrative and Financial Studies". Amman Arab University for Graduate Studies, Amman, Jordan, 2005.
[29] H. Najm. "Management Information Systems: Contemporary Entrance". Wael Publishing House, Amman, Jordan, 2005.

[30] A. S. Salwa. "The Role of Knowledge Management and Information Technology in Achieving Competitive Advantages in Banks Operating in Gaza Strip". Master of Business Administration, Islamic University, Gaza, 2008.

[31] A. Jazar and A. Talaat. "Proposed Project for Knowledge Management in Jordanian Public Universities, Unpublished Doctoral Thesis, Faculty of Higher Education Studies". Amman Arab University for Graduate Studies, Amman, Jordan, 2005.

[32] I. Fernandez, A. Gonzalez and R. Sabherwal. "Knowledge Management, Challenges, Solution, and Technologies". $1^{\text {st }}$ ed. Pearson Prentice Hall, London, United Kingdom, 2004.

[33] B. Mohammed and M. Ziad. "Knowledge Management between Theory and Practice". Jalis Al-Zaman Publishing House, Amman, 2010.

[34] J. Ashoc. "Knowledge Management an Integrated Approach". Pearson Education, Prentice-Hall, London, United Kingdom, 2004.

[35] M. Kamel. "Knowledge Acquisition, Wiley Encyclopedia of Electrical and Electronics Engineering". John Wiley and Sons, Inc., New York, United States, 1999.

[36] X. Zhang. "Understanding Conceptual Framework of Knowledge Management in Government (Condensed Version), Presentation on UN Capacity-Building Workshop on Back Office Management for e/m-Government in Asia and the Pacific Region, Shanghai, China", 2008.

[37] S. Zainab. "The Readiness of Public Organizations for Knowledge Management: A Case Study of King Abdul Aziz University in Jeddah, An Introduction to the International Conference on Administrative Development: Towards Distinguished Performance of the Government Sector, Riyadh", 2009.

[38] E. Carlevale. "Exploring the Influence of Information Overload on Middle Management Decision Making in Organizations, Doctoral Dissertation". University of Phoenix, United States, 2010.

[39] J. Hodge. "Examining Knowledge Management Capability: Verifying Knowledge Process Factors and Areas in an Educational Organization, Doctoral Dissertation". Northcentral University, United States, 2010.

[40] M. Ismail and Z. Yusof. "The impact of individual factors on knowledge sharing quality". Journal of Organizational Knowledge Management, vol. 2010, p. 327569, 2010.

[41] M. Raoufi. "Avoiding Information Overload-A Study on Individual's Use of Communication Tools, Proceeding of the $36^{\text {th }}$ Hawaii International Conference on System Sciences". 2003.

[42] M. Manovas. "Investigating the Relationship between Knowledge Management Capability and Knowledge Transfer Success, Mastery Degree". Concordia University, Canada, 2004.

[43] T. Zakia. "Knowledge Management: The Importance and Extent of Application of its Operations from the Point of View of the Supervisors and Administrator's Departments of the Department of Education in Makkah and Jeddah, Master Thesis, Umm Al-Qura University". 2009. 